\title{
CORRECTION
}

\section{Correction to: Long-term stability of results following surgery for obstructive sleep apnea (OSA)}

\author{
Paula Martínez-Ruíz de Apodaca ${ }^{1}$ (D) - Marina Carrasco-Llatas ${ }^{1}$ (D) - Silvia Matarredona-Quiles ${ }^{1}$ (i) . \\ Marta Valenzuela-Gras ${ }^{2}$ (I) . José Dalmau-Galofre ${ }^{1}$
}

Published online: 23 June 2021

(c) Springer-Verlag GmbH Germany, part of Springer Nature 2021

\section{Correction to: European Archives of Oto-Rhino-Laryngology \\ https://doi.org/10.1007/s00405-021-06781-x}

In the original publication of the article, in Table 3, the header of last column was published incorrectly as "IAH post 3rd control". The correct header should read as "AHI post 3rd control".

Publisher's Note Springer Nature remains neutral with regard to jurisdictional claims in published maps and institutional affiliations.

Marina Carrasco-Llatas marinacll@gmail.com

Paula Martínez-Ruíz de Apodaca pmruizdeapodaca@gmail.com

Silvia Matarredona-Quiles silvia.matarredona@gmail.com

Marta Valenzuela-Gras dra.martavalenzuela@gmail.com

José Dalmau-Galofre josedalmau@comv.es

1 Hospital Universitario Dr. Peset, Avenida Gaspar Aguilar 90, 46017 Valencia, Spain

2 Hospital Lluis Alcanyis, Carrer Xàtiva, Km 2, Xàtiva, 46800 Valencia, Spain 